\title{
Social reproduction of 'classes of labour' in the rural areas of South Africa: contradictions and contestations
}

\author{
Ben Cousins, Alex Dubb, Donna Hornby and Farai Mtero
}

\begin{abstract}
Marxist agrarian political economy has focused largely on the problematic of accumulation and its politics, but the dynamics of social reproduction in rural contexts remain somewhat undertheorised. These are explored through consideration of empirical evidence from communal areas and land reform farms in South Africa. Key arguments advanced are that social reproduction in such contexts include the reproduction of distinctive forms of marriage, systems of kinship and community membership, as well as of property relations that are not characterised by private ownership. Much social reproduction occurs outside of (direct) market relations, but it is nevertheless deeply conditioned and shaped by the dynamics of the wider capitalist economy, including in relation to wage labour and smallscale agricultural production. As a result, social reproduction in rural areas involves contradictions, tensions and contestations, and these are often at the centre of local forms of politics. The wider significance of these findings is discussed, and it is suggested that similar dynamics may be at work across the Global South.
\end{abstract}

\section{Introduction}

Marxist agrarian political economy has tended to focus on accumulation problematics, which were central in classic debates on the Agrarian Question (Byres 1996), which is understandable given the overall dominance of the logic of capital in a capitalist world. Within these debates, discussion of small-scale agriculture was largely orientated to questions surrounding accumulation (from 'above', 'below', or in some combination) and their historical or prospective contribution to national development. This concern was key in Africa, given the large proportion of small-scale producers, both before and following national independence, notwithstanding ongoing processes (permanent, non-permanent and cyclical) of urbanisation. A notable theoretical advance was re-conceptualising 'peasant' farmers as 'petty commodity producers', concentrating the contradictory relations of capital and labour in particular households, enterprises and even persons.

More recently, Bernstein (2010, 110) has argued that the 'classic' Agrarian Question has been 'resolved' on the global stage (even, and importantly, while remaining 'unresolved' in particular national contexts) and is increasingly being supplanted by a gathering general crisis of reproduction for 'fragmented classes of labour'. A key component of this 'Agrarian 
Question of Labour' is the growing number of rural households in the Global South, whose survival depends on the (direct and indirect) sale of their labour power, but who face mounting, complex and contradictory pressures on their social reproduction.

At the same time, a developing wider literature is placing renewed focus on transcending the dualism between 'accumulation' and 'social reproduction', as well as problematic analytical distinctions between 'public'/'private' and 'commodified'/'non-commodified' domains. This literature interrogates not only the inter-relation of accumulation and social reproduction (of both society at large and of particular classes) but their mutual constitution (Bhattacharya 2017; Ferguson et al. 2016). This is a fruitful area of engagement for Marxist approaches to rural class dynamics in the Global South in general, and Africa in particular, where tensions between accumulation and social reproduction, and their role in localised forms of politics, have long been noted (Bernstein 2010; Gibbon and Neocosmos 1985; O'Laughlin 1996).

This contribution discusses material from two cases in rural South Africa, and shows how land plays an enduring, albeit shifting, role in social reproduction, class differentiation and stratification amidst a wider and deepening 'fragmentation' of class realities. The cases illustrate how the contradictions of daily and generational reproduction are both reflected in, and act as vectors of change of, local social organisation and cultural norms.

It begins with a brief review of the recent literature on social reproduction in general, and observes that reproduction dynamics in rural economies of the Global South are distinguished by distinctive agricultural and natural resource-based livelihoods and property relations. The latter are often embedded within institutions that derive their legitimacy from 'custom' and other cultural forms as much as from state recognition. Cultural norms are often in tension with class relations, but are also fundamentally conditioned by how the latter condition and shape social reproduction.

To provide context for the in-depth case study material presented, the paper briefly summarises key aspects of the historical development of South Africa's racially inflected form of capitalist economy, in which self-provisioning through small-scale farming for domestic consumption and sale underpinned a system of cheap, migrant labour. It then describes the broad pressures on the social reproduction of 'classes of labour' in contemporary South Africa - both one of the world's most unequal societies and one characterised by extreme unemployment, including nearly 40 percent of working-age adults. Poverty is deepest in rural areas, where one third of the population resides. Farming is a significant source of income for only a minority of rural residents, most of whom rely heavily on social grants provided by the government.

The paper analyses the realities of social reproduction in two cases - in the Msinga communal area and in land reform projects in Besters, both located in rural KwaZuluNatal. It argues that household strategies for securing social reproduction are shaped by processes of class differentiation more broadly as well as locally. The contradictions of social reproduction under capitalism thus generate a range of tensions, often along axes 
of gender and generation, but underpinned by class, that are expressed in local politics. It is suggested that similar dynamics may be at work across the Global South.

\section{Theorising social reproduction}

According to Marx, the capitalist production process 'produces and reproduces the capitalrelation itself: on the one hand the capitalist, on the other the wage-labourer' $(1976,724)$. From the side of labour, wages are converted into

means of subsistence which have to be consumed to reproduce the muscles, nerves, bones and brains of existing workers, and to bring forth new workers into existence ... . The maintenance and reproduction of the working class remains a necessary condition for the reproduction of capital. But the capitalist may safely leave this to the worker's drives for self-preservation and propagation. (Marx 1976, 717-78)

From the vantage of capital, then, how workers reproduce themselves outside the 'cost' of their wages is their own business. At this level of abstraction, Marx largely assumed the cost of labour power to be equivalent to the wages required to cover the purchase of commodities necessary to workers' social reproduction. This allowed Marx to examine key dynamics of capitalist societies, such as how lowering the cost of 'necessary' commodities enhances profits through 'relative' surplus appropriation. However, this assumption also left important lacunae in relation to the determination of workers' needs in relations and processes outside of wage relations. Here Marx is uncharacteristically vague, for example in noting the 'production of labour power consists in his reproduction of himself or his maintenance' (Marx 1976, 274), and ... 'the number and extent of his so-called necessary requirements, as also the manner in which they are satisfied, are themselves the product of history'... . and thus 'the determination of the value of labour power contains a historical and moral element' (Marx 1976, 275).

Beginning in the 1960 s and 1970s, Marxist and feminist scholars began to place renewed emphasis on understanding social reproduction. They generated fierce debates on the role of domestic labour, and the incorporation and transformation of own production under colonial and imperial regimes (Meillassoux 1972). Analyses focused attention on how the reproduction of capital depends upon the social reproduction of labour through a wide range of 'non-commodified' forms of production and 'non-economic' relations. Although wages remain key for the purchase of commodities, the social reproduction of labour was also seen to involve, and rely on, institutions such as marriage, households and the state, and their governance of largely feminised unpaid labour, often under oppressive conditions.

Social reproduction is core to a wide range of current debates, extending beyond the household and its gendered power relations to encompass all the institutions and processes through which labour power is renewed (Ferguson et al. 2016, 31; Katz 2001). Indeed, the scope of 'social reproduction' is potentially, and even bewilderingly, vast. According to Fine and Saad-Filho $(2016,61)$, it involves a 'complex array of non-economic 
relations, processes, structures, powers and conflicts'. For Laslett and Brenner (1989, 382), social reproduction refers to:

the activities and attitudes, behaviours and emotions directly involved in the maintenance of life on a daily basis and intergenerationally ... (it includes) how food, clothing and shelter are made available for immediate consumption, the ways in which the care and socialization of children are provided, the care of the infirm and the elderly, and the social organization of sexuality.

Increasingly, Marxist-feminists see social reproduction not as a separate and autonomous, non-commoditised domain or social sphere, but as an integral feature of capitalist society that is deeply shaped and conditioned by the wider dynamics of capital- labour relations, changing regimes of accumulation, and their politics. Katz (2001,711), for example, defines social reproduction as a 'set of structured practices that unfold in dialectical relation with production, with which it is mutually constitutive and in tension'. She adds that 'the material social practices associated with its production [are] historically and geographically specific', and 'call forth a range of cultural forms and practices' (Katz 2001, 17). In dialectical fashion, 'patterns of social reproduction are shaped by and also shape socio-economic and political orders' (Bakker and Silvey 2008, 3). As Bhattacharya $(2017,59)$ asserts, social reproduction is not about 'two separate spaces and two separate processes of production, the economic and the social - often understood as the workplace and home'. It focuses on capitalism as a complex totality or connected whole, in which 'the economic impulse of capitalist production conditions the so-called noneconomic', while not determining it.

Some Marxist-feminists such as Picchio (1992) emphasise that capitalism both requires a sphere of non-commoditised social reproduction and tends to erode or destroy the relations that constitute it. Vogel (1983) asserts that there is a systematic (i.e. necessary and contradictory) relation between the production of labour power and the production of value or capital. Fraser (2016) argues that capitalism depends on several background conditions that it also tends to bring into crisis. Capitalism's 'drive to unlimited accumulation threatens to destabilize the very reproductive processes that capital - and the rest of us - need' (Fraser 2016, 103). If social reproduction is threatened, over time the effect will be that 'capitalism's accumulation dynamic effectively eats its own tail' (Fraser 2016, 103).

However, it is also apparent that in periods of accumulation characterised by rapid growth and rising wages, as occurred in developed capitalist countries in the post-World War II 'golden age' from the mid-1940s to the early 1970s, accumulation and enhanced living standards (i.e. social reproduction) were mutually supportive to some degree. In this period accumulation tended to be based on the appropriation of relative rather than absolute surplus value, and expanded markets for consumption goods and services facilitated accumulation. State-funded education and health services were provided on a larger scale, to the benefit of both working populations and capital. Indeed, whether won 
or improved through political struggle 'from below' or reforms 'from above', public services represent one key area 'outside' direct wage-relations that not only improved living standards, but both relied on and conditioned wider commodity relations.

In this period, the mutual conditioning of accumulation and social reproduction was partial and uneven, and marked by class, gender, race and other social differences, as well as by location within global capitalism's uneven geography. Notions of a 'family wage', for instance, reproduced heteronormative households under male authority and involving robust gender differences (Fraser 2016, 111). Today, in an era of financialised capitalism underpinned by neoliberal policies, the contradictions between accumulation and social reproduction have deepened (Fine and Saad-Filho 2016, 162-68). They have been exacerbated in the current period of stagnation initiated by the global financial crisis of 2007/2008, as well as by the austerity policies of many governments. As Bakker and Silvey $(2008,4)$ emphasise, global neoliberal restructuring has seen 'increasing tensions, contradictions and crises emerging within the domain of social reproduction', in part through its increasing privatisation, marketisation and informalisation. These general tendencies are pervasive, but have distinctive features in agrarian economies in the Global South.

\section{Social reproduction in agrarian economies in the Global South}

Social reproduction takes place in particular ways in economies in the Global South where small-scale agriculture is engaged in by significant numbers of people. It includes the use of crop and livestock production for domestic consumption and cash earnings, and the gathering of natural resources such as wild foods, fuelwood, timber, and materials for craft production, for both own use and sale. Many natural resources are found on the commons. All of these activities are structured by unequal and gendered divisions of labour and power relations, and women assume major roles in the so-called 'subsistence economy', which includes small-scale production, fuel and water collection, domestic labour and the care of young children, the frail elderly and the sick (Razavi 2009, 206).

Production and reproduction in both non-commodified relations and in markets are as dynamically intertwined in agrarian societies as in developed capitalist economies, but in distinctive ways (Chung 2017). Access to and control over land and natural resources, in conjunction with the labour required for production and gathering, emerge as key to the sphere of social reproduction in agrarian economies (Naidu and Ossome 2016, 61). Given the generalised commodification of contemporary life under capitalism, cash income is required for many items of subsistence. Employment for wages, in cash or in kind, locally or farther afield, is usually necessary, and both types of employment and levels of remuneration are gendered and unequal. Employment can both constrain own production (e.g. by drawing away labour; or providing an exit from the rural economy) or support it (e.g. through providing cash to survive or to purchase inputs). 
Pressures on social reproduction arise from the unequal character of class relations under capitalism, and are key to class differentiation in agrarian economies. ${ }^{1}$ As Bernstein (2010, 103) argues, drawing from Gibbon and Neocosmos (1985), small-scale farmers should be conceived as 'petty commodity producers' rather than 'peasants' (often portrayed as existing outside of capitalism's class dynamics and contradictions). ${ }^{2}$ Petty agricultural commodity producers combine the class places of capital and labour within their enterprises: they possess means of production, unlike landless workers, and are in this sense, capitalists, but they also use their own labour (unlike capitalists, who hire in workers). Often sexual divisions of labour within farm households see men occupying the effective position of capital (by directing the production process and appropriating proceeds) and exploiting women and children engaging in both productive labour and social reproductive activities. As Bernstein $(1986,22)$ puts it:

In terms of the enterprise as a whole, and its fortunes (reproduction, decomposition, transformation), its distinctive combination of class places can help explain the contradictions petty commodity producers often confront between reproducing themselves as labour (daily and generational reproduction) and capital (maintenance, replacement, and possibly expansion of the means of production).

By combining the positions of capital and labour, petty commodity producers consequently also concentrate contradictory imperatives to secure both social reproduction and valorisation. Bernstein $(2010,18-20)$ proposes that this is expressed in meeting the demands of four competing 'funds': a consumption fund for food, clothing, shelter etc., including for those too young or unfit to work; a replacement fund for productive capital (e.g. seed, tools, draught animals) - but also for labour, through generational reproduction in childbearing and raising, as well as care of the old and unfit; a ceremonial fund, for activities that 'create and recreate the cultures and social relations of farming communities, such as rituals and festivities' (Bernstein 2010, 20); and a fund of rent, where farmers make payments to others such as landlords, moneylenders or states.

The notion of a 'ceremonial fund', first proposed by Wolf (1966), suggests that social reproduction in agrarian contexts should be understood as involving more than daily and generational reproduction, and more than the reproduction of the capital-labour relation, or other kinds of class relations. It involves reproduction of the social, i.e. of social relations more broadly. Moreover, the manner and degree to which the demands of the ceremonial fund are met under the conditions imposed by capitalist value relations contributes to the structuring of wider social institutions and relations, without necessarily determining their particular form.

\footnotetext{
1 The degree to which this tendency is evident in practice is highly contingent, and does not necessarily manifest in clear trends (Bernstein 2010, 109).

${ }^{2}$ This view has been widely adopted, for example by scholars of rural India such as Harriss-White (2012) and Lerche (2013), and by Oya (2010) for Africa, as well as in the South African case by Cousins (2011) and Dubb (2015).
} 
This reading of the 'ceremonial fund' is consonant with Bhattacharya's (2017) characterisation of the efforts in social reproduction theory to transcend a dualistic conceptualisation of class and social reproduction. The question is not simply one of seeking to identify social institutions that 'pre-date' class in order to analyse how they 'mediate' class (Mezzadri 2016, 1880), nor to uncover how accumulation in a 'public' sphere of 'commodified' relations is founded upon a prior binary antagonism of accumulation with 'private' and 'non-commodified' relations. Rather, it is of one of how the actual conditions of labour power's reproduction (in an expansive sense that includes institutions, activities and antagonisms outside of employment) is continually being re-shaped and re-invented by its relation to capital accumulation in a dynamic and structured, but non-determinate manner.

Given the particular importance in the Global South of land and natural resources, and thus property rights, a key aspect of social reproduction is how access to and control over these resources are structured and governed. This involves socially and culturally defined identities and relations, and finds ideological expression in notions of 'community' and 'tradition'. 'The social' thus has to include questions of kinship, family, marriage and the constitution of households; community membership, the 'cultural' sphere and the ceremonial economy; and property rights.

These kinds of social institutions and their relation to land are certainly historical in character, but they cannot be seen simply as 'independent' variables conditioning accumulation. One striking illustration of this is provided by Capps' (2016) analysis of the emergence and subsequent evolution of the BaFokeng chieftaincy as a form of 'tribal landed property'. As an unintended consequence of state nationalisation of mineral rights, the Bafokeg ruling elite has shifted from being 'rentiers' amassing royalties under a tribaltrust regime, in tension with mining capital, to becoming direct shareholders in such capital, with diversified financial interests.

The matter is, moreover, not simply one of transformations from 'above'. Ferguson (2013) discusses the centrality of land for the rural poor in contemporary Southern Africa within 'distributive relations'. These involve not only land-based production, but also accessing a 'rightful share' of cash and other forms of support deriving from membership or ownership-based claims on citizenship, indigeneity or ethnicity. 3 Land is now being used to reinvent circuits of distribution in economies where both circular migrant labour is eroding and large-scale commercial agriculture renders small-scale farming uncompetitive, and where other sources of income, such as welfare grants, are being distributed through new sets of social relations (Ferguson 2013, 171). 'Land' (often as 'place' rather than as productive resource) can anchor such relations, e.g. as somewhere to properly bury the dead, provide a place of connection and return for kin, establish continuity with the past, underpin the powers of traditional authorities, and symbolise

${ }^{3}$ See Ferguson (2015) for an expanded version of the argument. 
collective identity and belonging (Ferguson 2013, 168). In this view, land is a vital component of social reproduction even when its productive use is marginal or absent.

\section{Fragmentation of classes of labour and the crisis of social reproduction}

Bernstein (2010) locates the reproduction squeeze facing small farmers today within the global reality of the increasing (structural) fragmentation of 'classes of labour', 4 by which he means a set of people depending, directly and indirectly, on the sale of their labour power for their daily reproduction:

The working poor of the South have to pursue their reproduction through insecure, oppressive and typically increasingly scarce wage employment and/or a range of likewise precarious small-scale and insecure 'informal economy' survival activity, including marginal farming. In effect, livelihoods are pursued through complex combinations of employment and self-employment (Bernstein 2010, 111).

'Fragmentation' refers in part to hybrid and diverse combinations of precarious forms of livelihood and sources of income available to classes of labour in global capitalism today, as well as the 'forms of differentiation and oppression along intersecting lines of class, gender, generation, caste and ethnicity' (Bernstein 2006, 455). The politics of the poor are often equally fragmented.

In an illuminating analysis of the agrarian question in Mozambique, O'Laughlin (1996) shows how two different but inter-related processes of class formation occurred in the countryside in the colonial period: (1) diversification of rural livelihoods, and (2) class stratification. The former reflects changes in the way that people organised their work and reproduction as commoditisation proceeded; the latter refers to the processes through which sharp differences emerged between households in relation to control of the means of production. Gendered divisions of labour in both production and reproduction are key to both processes. Diversification and stratification can proceed together as wage labour and market relations expand over time, but their rhythms may be very different, especially in contexts where indigenous capital was suppressed. The notion of 'fragmentation' resonates strongly with this analysis. In her view, the imperatives of securing the social reproduction of the rural population, as well as the variety of ways in which this was shaped by the dynamics of rural class formation in the colonial era, are central features of the agrarian question.

In her 1996 paper O'Laughlin rarely uses the term 'reproduction', and instead refers to 'everyday subsistence', 'basic needs' or 'livelihoods'. However, it is clear that these terms refer to the same substantive realities of social reproduction discussed by other Marxistfeminists. Similarly, Stevano (2017) for example has demonstrated the gendered character of 'fragmentation' in cycles of food insecurity in northern Mozambique. Here the seasonal

\footnotetext{
${ }^{4}$ The term 'classes of labour' is preferred by Bernstein to the older vocabulary of 'proletariat' and 'semi-proletariat' because the latter are often encumbered by problematic assumptions, such as functionalist readings of Marx's notion of the 'reserve army of labour'. For illuminating analyses drawing on this concept, see Li (2009), Lerche (2011) and Mezzadri and Srivastara (2015).
} 
character of agricultural work, together with reliance on multiple and precarious incomes, impinges on domestic activities typically performed by women, and undermines the regular and diverse diet of households. O'Laughlin's recent work on the 'production of affliction' amongst rural populations of Southern Africa further shows how their health status, and thus biological reproduction, continues to be negatively affected by the 'structural contradictions' and dynamics of the labour-reserve systems that emerged in the course of capitalist development in the region (O'Laughlin 2013, 194; see also O'Laughlin 2017).

\section{Capitalist development in South Africa}

We now turn to the case of South Africa. A sketch of the history of capitalist development in South Africa provides some context for the discussion of contemporary dynamics. The development of capitalist agriculture in South Africa did not promote industrialisation, as might have occurred elsewhere (Byres 1996); rather, the reverse was true. Industrialisation in South Africa was initiated in the final three decades of the nineteenth century following the discovery of diamonds in 1867 and gold in 1886, prompting an aggressive colonial expansion to underpin significant levels of foreign investment. Previously, the commercial economy was largely concentrated around the ports of the Cape and Natal, while the interior was largely agrarian in character, supporting a small population of indigenous peoples and an even smaller group of European settlers exercising political power. The arrival of mining and its ancillary industries not only tightened links to world competition and trade (comprised mainly of exported minerals and imports of other goods) but underpinned tendencies to urbanisation.

The social reproduction of African labour played an early and calculated role in shaping these processes. Both mining and an emergent (white) capitalist agriculture were dependent on a low-wage regime for their growth. State policies of racial segregation, movement and widespread African land dispossession (including of increasingly marketorientated producers) provided extensive land resources to white landed property, and a general supply of African labour 'cheapened' by their partial survival through own production in the reserves and as labour-tenants on white farms. African social reproduction was reconfigured as spatially dispersed combinations of wages and own production, mediated by highly gendered divisions of labour and lineal networks, which continue to resonate today (Bernstein 1996; Innes 1984; Wolpe 1972).

Whereas previously the reserve system had been geared to coercing a supply of 'cheap' unskilled African labour, under apartheid it was increasingly orientated to housing an African population 'surplus' to capital's requirements. For Wolpe (1972), the final erosion of the 'subsidy' provided by African subsistence in over-populated reserves was demonstrated by the apartheid state's attempt to recast the reserves as nominally independent 'homelands'. It also involved dispossession and resettlement of large numbers of black South Africans, with Platzky and Walker (1985) estimating that 3.5 million Africans were subject to forced removals between 1960 and 1983, 1.1 million of which came from white farming areas. 
Arrighi, Aschoff, and Scully (2010) argue that the unintended wider consequences of these policies were negative for South African capitalism: a narrow domestic market was impeded by stagnant black wages; small-scale agriculture in the reserves largely collapsed, and, together with the racially exclusive character of social welfare, limited the potential for import-substituting growth in the manufacturing sector. By the 1980s, the contradictions of apartheid South Africa's particular path of capitalist development had become increasingly fierce. 5 As shown below, these contradictions have not been resolved in the post-apartheid era, not least in relation to the social reproduction of the rural population.

\section{Fragmented classes of labour and social reproduction in post-apartheid South Africa Policies and outcomes}

Since 1994, state policies in South Africa have combined conservative economic policies with a range of programmes of social provision designed to ameliorate poverty and inequality. The structure of the economy carries key continuities with the past (e.g. capital in most sectors remains highly concentrated; Bosiu et al. 2017, 30), but significant changes are evident (Seekings and Nattrass 2015). The contributions of key sectors such as mining, manufacturing and agriculture to gross domestic product (GDP) and employment have declined over the past two decades, being supplanted by an expanding service sector (especially 'business' and 'financial services') and government spending. The economy has increasingly internationalised, both 'inwardly' (as more foreign companies operate in South Africa) and 'outwardly' (as South African companies shift parts of their operations to other countries, including through cross-listing in different stock exchanges, in a process of 'capital flight'). Levels of investment in the productive economy by leading firms are low (Bhorat et al. 2014).

Most corrosively, South African capitalism is unable to provide employment to large numbers of people. Unemployment is very high: currently standing at around 27 percent if only active job seekers are counted, and 37 percent if those too discouraged to seek work are included (Stats SA 2017a). Many of those employed, particularly in casual or temporary work, earn very low wages - these are the 'working poor'. Young South Africans are particularly badly affected: in 2017, nearly a third of all those between ages 15 and 24 were not in employment, education or training (Stats SA 2017b).

Over half of South Africans experience poverty, and income inequality remains amongst the highest in the world, with a Gini coefficient of o.68. Inter-racial inequality has declined somewhat, but intra-racial inequality is increasing as class differences surpass those of race (Seekings and Nattrass 2015, 51-53). Without the massive programme of 17 million social grants (benefitting around one third of a population of 55 million) with a value of around 3.5 percent of GDP, poverty and inequality would be even deeper. Social

\footnotetext{
${ }^{5}$ The character of apartheid South Africa's contradictions is more complicated and nuanced than sketched here, and there are important differences in views amongst scholars, including those cited above and Burawoy (1976), Fine and Rustomjee (1996), Gelb (1991), Hart (2002) and Legassick (1980).
} 
protection now constitutes around 16 percent of the national budget, with education comprising 20 percent and health services 12 percent.

Whether this hybrid of conservative economic policies and social welfare can be sustained for much longer is in doubt. Economic growth has slowed in recent years, and is currently less than one percent per annum. There is clear evidence that many parastatals and stateowned enterprises have been 'captured' by a corrupt group within the ruling party, who provide rent-seeking opportunities for a small number of black and foreign capitalists (Bhorat et al. 2017). Currently, there is a generalised sense of social and political crisis. For the poorest half of the population, a key element of this crisis is pressure on their social reproduction.

\section{Poverty, inequality and social reproduction}

Over half of the South African population experiences income poverty, according to a recent report from government (Stats SA 2017a; see Table 1). Three poverty lines are shown; the lowest, the food poverty line (FPL), refers to individuals unable to purchase or consume enough food to meet minimum per-capita-per-day energy requirements for adequate health' (14). The other two, a 'lower bound' poverty line (LBPL) and an 'upper bound' poverty line (UBPL), include some non-food components, but the LBPL requires individuals sacrifice some food to obtain these, while at the UBPL, adequate food and non-food items can be purchased. These data show that poverty declined from 2006 to 2011, in line with the general trend for most of the post-apartheid period, but has increased since.

In relation to spatial location, poverty is deepest in rural areas, where the majority of the poor (53.5 percent) reside (68). In 2015, 81.3 percent of rural dwellers fell beneath the UBPL, 65.4 percent beneath the LBPL, and 45.6 percent below the FPL. Provinces with the highest poverty head counts were Limpopo, Eastern Cape and KwaZulu-Natal (66), each with very large proportions of their populations in communal areas, the former 'native reserves'. In relation to the basics of social reproduction (food, shelter, energy, water, sanitation and health), 80.5 percent of poor households (defined by the UBPL) had access to electricity, 59 percent to piped water and 39.3 percent to flush toilets (101). Many were subsidised from municipal rates paid by wealthier households and from grants from central government (Seekings and Nattrass 2015, 186). Most of South Africa's poor, including those in rural areas, purchase the bulk of their food. As elsewhere, the proportion of income the poor spend on food is much higher than for the non-poor, at 30 percent and 10.5 percent respectively in 2015 (Stats SA 2017a, 100). 
Table 1. Poverty headcounts in South Africa, 2006-2015.

\begin{tabular}{llll}
\hline Poverty headcounts & 2006 & 2011 & 2015 \\
\hline \% of population that is UBPL poor & 66.6 & 53.2 & 55.5 \\
Number of UBPL persons (millions) & 31.6 & 27.3 & 30.4 \\
\% of population that is LBPL poor & 51. & 36.4 & 40.0 \\
Number of LBPL persons (millions) & 24.2 & 18.7 & 21.9 \\
\% of population that is FPL poor & 28.4 & 21.4 & 25.2 \\
Number of FPL poor persons (millions) & 13.4 & 11.0 & 13.8 \\
\hline
\end{tabular}

Note: $U B P L=$ upper bound poverty line; $L B P L=$ lower bound poverty line; $F P L=$ food poverty line.

Data source: Stats SA (2017a, 14).

South Africa continues to experience high rates of HIV and AIDS. In 2016, the country had the largest number of HIV-positive people in the world (7.03 million, or 12.7 percent of the population), with particularly high prevalence rates for adults younger than $5^{0}$ (18.9 percent), and particularly women younger than 50 (22.3 percent) (Stats SA 2016, 7). The spread of the pandemic has been contained by programmes to address mother-tochild transmission and provision of antiretroviral medications on a large scale. However, for young females in particular, the disease remains a serious threat to their health.

High rates of sexually transmitted disease in South Africa have long been associated with the migrant labour system that was integral to industrialisation (Andersson and Marks 1988). In the post-apartheid era, the HIV/AIDS pandemic can be partly explained by (or perhaps, following O'Laughlin (2017), produced by), rising unemployment and other forms of social inequality, and associated dramatic declines in the rate of marriage amongst the African population, and the increased geographic mobility of women, as Hunter (2007) suggests. Many younger women are engaged in circular migration pivoted on a rural home, and in urban contexts often live in informal settlements. Here the rate of HIV/AIDS is twice as high as elsewhere, and residents are 'typically young, unmarried and without secure work' (Hunter 2007, 690). Often these young women transmit resources to their mothers, who care for their children at a rural home; thus, kinship ties are strengthened through the sexual economy, as well as the redistribution of income from social grants (Hunter 2007, 698).

Hunter argues (Hunter 2007, 694, emphasis in original) that young generations of South Africans are experiencing a 'simultaneous collapse of both agrarian and wage livelihoods, with very important consequences for marriage, household formation and sexuality'. Changes in marriage practices are a key component of the reconfiguration of social reproduction in the post-apartheid era. Posel and Rudwick (2013) analyse data from representative surveys which show that in 2010 only 41 percent of African women had ever been married, compared to 81 percent for white women. Around 73 percent of African women between the ages of 20 and 30 had never been married, and were not cohabiting with a partner, compared to 28 percent of African women between the ages of 40 and 50 . 


\section{South Africa's fragmented classes of labour}

Many South Africans are experiencing severe pressure on their social reproduction, in part because of the 'fragmentation' of 'classes of labour'. In the absence of recent Marxist analysis of class structure in South Africa as a whole, the Weberian approach of Seekings and Nattrass $(2015,118-22)$ is helpful for describing the contours of class-based inequality (if not the underlying dynamics and relations that produce these inequalities). ${ }^{6}$ They characterise the class structure of South Africa in 2008 in terms of three broad strata, each comprising several classes (see Table 2). There is an upper class, including the 'upper middle classes' and comprising business, professional and management, and selfemployed people, constituting 17 percent of households and earning 55 percent of all income. Lower middle and working classes comprise semi-professionals, intermediate groups, petty traders and the core working class, and make up 46 percent of all households earning 35 percent of all income. The working poor, underclass and others make up 36 percent of all households and earn 10 percent of all income.

Table 2. Class structure in South Africa, 1993 and 2008.

\begin{tabular}{|c|c|c|c|c|c|}
\hline \multirow[b]{2}{*}{ Strata } & \multirow[b]{2}{*}{ Classes } & \multicolumn{2}{|c|}{1993} & \multicolumn{2}{|c|}{2008} \\
\hline & & $\begin{array}{c}\text { Share of } \\
\text { households (\%) }\end{array}$ & $\begin{array}{c}\text { Share of total } \\
\text { income }(\%)\end{array}$ & $\begin{array}{c}\text { Share of } \\
\text { households (\%) }\end{array}$ & $\begin{array}{c}\text { Share of total } \\
\text { income }(\%)\end{array}$ \\
\hline \multirow[t]{4}{*}{ Upper classes } & Business & 1 & 11 & 4 & 19 \\
\hline & $\begin{array}{c}\text { Professional and } \\
\text { management }\end{array}$ & 9 & 30 & 11 & 29 \\
\hline & Self-employed & 2 & 4 & 3 & 7 \\
\hline & Subtotal & 12 & 45 & 17 & 55 \\
\hline \multirow{5}{*}{$\begin{array}{c}\text { Lower middle and } \\
\text { working classes }\end{array}$} & Semi-professional & 5 & 8 & 3 & 4 \\
\hline & Intermediate & 19 & 22 & 23 & 18 \\
\hline & Petty traders & 5 & 4 & 11 & 7 \\
\hline & Core working & 19 & 11 & 10 & 6 \\
\hline & Subtotal & 48 & 45 & 46 & 35 \\
\hline \multirow{4}{*}{$\begin{array}{l}\text { Working poor, } \\
\text { underclass and } \\
\text { others }\end{array}$} & Marginal working & 12 & 4 & 8 & 3 \\
\hline & Underclass & 29 & 6 & 12 & 2 \\
\hline & Other & & & 16 & 5 \\
\hline & Subtotal & 41 & 10 & 36 & 10 \\
\hline Total & & 100 & 100 & 100 & 100 \\
\hline
\end{tabular}

Data source: Seekings and Nattrass $(2015,119)$.

Seekings and Nattrass comment that between 1993 and 2008, 'the class structure ... changed marginally whilst remaining fundamentally the same' (118). The rich did particularly well in the early 2000s, and some of their gains were redistributed to the poor via taxes, social grants and so on. The core working class (comprising mostly lessskilled workers in industry) shrank most, and less-skilled workers became increasingly restricted to informal and non-tradeable sectors. More than half of the lower classes were rural, and in the former reserves, 63 percent of the population was lower class (121). The lower classes include the working poor in domestic work and agriculture, hawkers and

${ }^{6}$ For other analyses of aspects of class structure in South Africa see Alexander et al. (2013), Southall (2016), and Zizzamia et al. (2016). 
others in 'survivalist' self-employment, workers in casual and other informal employment, and many of the unemployed (130).

In our view, Bernstein's concept of 'fragmented classes of labour', together with O'Laughlin's emphasis on the importance of paired processes of livelihood diversification and class stratification, are key to understanding the contradictions of South African capitalism. This is true in relation to both historically determined conditions and contemporary patterns of reproduction and change, the key point being that formal employment by itself is not able to satisfy the social reproduction needs of the majority (despite being a crucial component of social reproduction).

All of those designated as 'lower class' by Seekings and Nattrass can be characterised in this manner, as well as some in the middle stratum. This suggestion is consistent with Zizzamia et al.'s (2016) analysis, which distinguishes those who face an above-average risk of slipping into poverty - the vulnerable - from the more secure 'middle class', who have a below-average risk of entering poverty. In 2014/2015, the vulnerable constituted 18 percent of the population, with the poor at 65 percent, the secure middle class at 13.5 percent and the elite at 3.5 percent (29). In the absence of jobs, social grants and other forms of public provision are crucial for the social reproduction of 'classes of labour'.

\section{Social reproduction and its contradictions in South Africa's rural areas}

We turn now to our two in-depth case studies. One is located in South Africa's 'communal areas', as the former native reserves are now known, home to one-third of the population (around 18 million people). The other is on farms redistributed through post-apartheid land reform and collectively owned by beneficiaries. Aspects of rural social reproduction in such contexts that are well described in the literature include: the absence of significant income earnings from small-scale agriculture for the majority of rural households; diversification of livelihood strategies; purchase rather than production of most food; dependence on social grants as the main source of cash income; and a high prevalence of HIV/AIDS (Neves and Toit 2013).

Less commonly discussed, but also key to understanding social reproduction in these contexts, are processes of social differentiation by class, gender and generation; the key role of livestock in both livelihoods and ceremonies; the continuing salience of 'custom' in social relations and identities, including processes of gaining access to land; the socially embedded character of property rights; gendered and generational tensions within rural households and homesteads; how emerging contradictions in social life as 'custom' and 'tradition' are simultaneously asserted and undermined; and the general significance of the ceremonial economy. Tensions also abound in many areas in relation to the 'customary' powers of unelected chiefs in local-level governance, underpinned by their key roles in land allocation and administration (Capps and Mnwana 2015). Contestations around the chieftaincy are in part rooted in the contradictory pressures of social reproduction, given that access to land and natural 
resources continues to be critically important for many households and is mediated by 'custom'.7

These issues are explored in the cases, based on field research over several years by two of the authors. Research methods combined intensive and extensive approaches (Sayer 2010), the former comprising direct observation, in-depth interviews, life histories and enterprise budgets, and the latter household surveys and enterprise budgets.

\section{Msinga district in kwazulu-Natal}

This case shows how social reproduction is inseparable from and deeply conditioned by the character of the capitalist economy, both nationally and in its local manifestations. ${ }^{8} 8$ Land tenure in Msinga is 'customary' in character, but there are growing tensions around residential land as a result of declining rates of marriage, and associated shifts in how homesteads, the key locus of social reproduction, are established. Access to high-value irrigated plots for fresh produce is also governed by customary tenure, as well as a 'socially embedded' rental market, and these constrain accumulation. Local politics is often focused on competing ideas about 'custom' and 'tradition', in relation to land but also social institutions.

In 2011 Msinga was rated as the municipality with the deepest poverty in KwaZuluNatal province. It is located in a dry to semi-arid zone with average rainfall of 500$600 \mathrm{~mm}$ per annum, but is densely populated. It has a long history of labour tenancy on neighbouring white farms, forced removals, labour migration to the Witwatersrand, and stock theft. In many ways, Msinga exemplifies the legacies of dispossession, the labourreserve system and the precariousness of social reproduction in rural South Africa more generally.

Dryland cropping in Msinga has been in decline for many years, but around 1500 households (of a total of 38,000 households in the area) grow vegetables and green maize, for sale on two irrigation schemes. This scarce irrigation land is in high demand. The ownership of livestock is unequal, but cattle (held by around 40 percent of house-holds), goats (69 percent) and indigenous poultry ( 91 percent) remain important for consumption, marriage feasts, and funerals and other ceremonies, as well as occasional sales. There is an active local market in goats required for ritual slaughters - more so than in relation to cattle. Access to land is crucial for establishing a homestead, as well as for cropping and the grazing of livestock on the commons.

Detailed research on the largest irrigation scheme in Msinga, located at Tugela Ferry, reveals irrigated plots were the main site of household food production (i.e. 'subsistence') by local residents until the early 1980s, when traders with pick-up trucks arrived. The traders offered to purchase truckloads of fresh produce for retail farther afield, and led

\footnotetext{
${ }^{7}$ The politics of the chieftaincy in contemporary South Africa is complex, and space does not allow further discussion here. See Capps (this issue) for in-depth analysis from a Marxist perspective.

${ }^{8}$ This material is based on Cousins (2011, 2013a, 2013b).
} 
plot holders to focus on production for sale. The main crops grown are green maize, tomatoes, sweet potatoes, cabbages, spinach and other green leafy vegetables. Individual plots range from 0.08 to 0.2 hectares in size, with a mean of around 0.1 hectares. Many farmers borrow or informally rent in uncultivated plots held by others, and the mean number of plots cultivated is 4.3 (around $0.4 \mathrm{ha}$ ). A few famers plant lucrative but illegal plots of marijuana along the canals and next to the Thukela River. It is possible to cultivate three crops a year on a single plot, and almost all farmers plant green maize. They produce some of the earliest maize in the province, with cobs sold as far afield as the main cities in the province. Many crops are purchased at the farm gate by traders. Some farmers transport their crops to nearer small towns for direct sale to hawkers or consumers. Over 70 percent of crops planted are profitable, but the estimated net profit per farmer per annum is modest, averaging R6700, or R558 per month in 2011, around 50 percent of the state old age pension. 9

The great majority of irrigation plot farmers (88 percent) are women, who work on their plots on most days, as well as undertaking domestic labour in their homesteads. The distribution of plots is not very uneven, with only 11 percent of farmers cultivating over 6 plots, and very few more than 10 plots. There are few dramatic differences between smaller and larger cultivators, with the latter having slightly higher numbers of household members in permanent jobs or earning income from farming. Some clear differences do exist in relation to agriculture, with larger cultivators owning more agricultural assets and larger numbers of livestock than smaller cultivators. They also employ more local people in specific piece-work tasks such as weeding, watering or harvesting of crops. Many temporary workers are drawn from households without plots, and wages are paid in cash or in kind. Survey data suggest that households without plots tend to own fewer assets than those with plots, own fewer livestock, and have fewer members in permanent employment.

Accumulation in small-scale agriculture is not entirely absent in Msinga, but it is highly constrained. Most income earned from crops or livestock sales is used to support social reproduction, including purchases of food. None of the larger cultivators on the irrigation schemes relies solely on agriculture, and permanent jobs are an important source of income in these households. In addition, all receive at least one social grant, either a pension or a child support grant. Irrigated agriculture for the market is seen by most farmers as a valuable income supplement to formal or informal employment, or self-employment, or received in social grants. Greatly expanded access to irrigated plots by would-be accumulators would constitute a threat to the key role of fresh produce income in the social reproduction strategies of the majority of plot holders. The only partially commoditised informal land rental market provides limited opportunities for expansion, and is hence a key constraint on accumulation.

\footnotetext{
${ }^{9}$ The state old age pension was worth R1140 per month in 2011/2012.
} 
More widely, virtually all Msinga households depend heavily on social grants, but given their low cash value many men and younger women are often absent, seeking wage employment. The great majority of the population of Msinga lives in poverty. Government jobs for teachers, nurses and administrators are available for only a better educated minority, who constitute a local elite. Some also cultivate irrigated plots, own larger herds of livestock and operate small businesses (e.g. small shops or taxi services).

In Msinga, as in communal areas in general, access to land is central to establishing and socially reproducing households. The land tenure system in Msinga is 'customary' in character, and includes common pool resources for grazing and natural resources. Chiefs provide an oversight role, but most land administration occurs at the neighbourhood level. Families are allocated residential plots for the establishment of a homestead, but arable land is limited and many households no longer cultivate dryland crops - even when they do hold fields. Many households, however, cultivate a small garden to supplement their food supply.

Residents of Msinga articulate a 'normative ideal' of how land should be allocated, used and administered, which involves a distinctive set of organising principles. Rights and obligations are defined through membership of families, households, kinship groups, neighbourhoods and 'tribal communities'. The key principle is that married people with children should be allocated land on which to establish a homestead and gain access to natural resources to support their families. Land is allocated to a household, under the authority of the household head, understood to be a senior male.

The extended family remains the basic unit of social organisation. Marriage establishes relationships between two descent groups, effected by payments of bridewealth (ilobolo) that transfer the rights to women's reproductive capacity to her husband's family. Descent is patrilineal, and a central concern for families is preserving the identity of the male lineage and its connection to past generations, symbolised in the family surname. Marriage is virilocal and children belong to the husband's family. Together with gender, family membership is a key determinant of social identity; it forms the basis of a web of relationships, rights and obligations.

The contradictions of social reproduction in communal areas are evident in discrepancies between these normative ideals of social organisation, derived from the structure of social relations in the precolonial era, and current practices. Marriage is in decline, partly as a result of the growing difficulties experienced by young men in their attempts to find wage employment, and partly due to reduced levels of control of the labour of women, now the main recipients of government social grants. Survey data reveal that 56 percent of adults have never been married, and that only six percent had entered into a full traditional marriage.

Increasing numbers of unmarried women with children are now requesting land to be allocated to them in their own names, alongside profound shifts in marital practices. 
Particularly notable is: (1) increasing numbers of women live within their father's (or brother's) homesteads, bearing and raising children outside of a stable, co-residential relationship; and (2) increasing numbers of co-habiting couples only 'partially marry', alongside a growing prioritisation of registration of marriage over the completion of marital rituals and practices prescribed by custom. There is also a significant increase in numbers of female relatives accommodated within homesteads, but outside of the patrilineal system. These include unmarried, divorced or separated daughters, and sisters, aunts and great-aunts on either the husband's or the wife's side, together with their descendants. Because these women's surnames may differ from the 'household surname', they are not viewed as full-fledged family members.

A new form of marriage, known as uganile, has emerged. This involves pregnant women moving to reside at their husband's homes after 'damages' have been paid. Many of these women opt to register such marriages at the magistrate's office, since this enables them to claim pension or life insurance payouts to which their husbands contributed in periods of formal employment. The distinction between 'married' and 'unmarried' women is not always clear cut, as the payment of cattle as damages to the female partner's family blurs distinctions between an iqhikiza (an unmarried woman in a relationship with a man, possibly with a child) and an umakoti (a young wife).

Discrepancies between cultural norms and actual practices underpin tensions in Msinga within and between families, often expressed along gendered and generational lines. In some areas, an unmarried woman requesting land must have sons (who carry the surname of the lineage) before she can be allocated land, but in other areas women with daughters can be allocated land. One of the traditional councils ${ }^{10}$ in the Msinga municipality, that of the Mthembu, is strongly opposed to the allocation of land to unmarried women with children. Fearing violence as a result of 'boyfriends' visiting such women, the council instead encourages site allocation within the boundaries of the umuzi for single mothers to build a home. In contrast, the neighbouring Mchunu Traditional Council decided in 2009 that land to establish a homestead could be allocated to any single person, male or female, genuinely in need. The council qualified this right by requiring that residents in the neighbourhood provide approval, and that traditional leaders oversee the process.

By 2015, allocations of land to single people were occurring on a significant scale in both the Mthembu and Mchunu areas, but 'custom' continued to be a site of tension and contestation, within and between households and families, as well as within 'tribal' politics. Factional violence within and between different residential units continues to erupt periodically. Other common axes of conflict are gender and generation, as 'custom' and 'tradition' are simultaneously asserted and adapted by women and men, and younger and older people.

\footnotetext{
${ }^{10}$ Traditional councils began to be established in all communal areas following approval of the Traditional Leadership and Governance Framework Act of 2003, many being formed on the basis of apartheid-era (and thus highly controversial) Tribal Councils (Claassens 2015).
} 


\section{Land reform farms in Besters, KwaZulu-Natal}

This case is not located in a communal area, but describes aspects of accumulation and social reproduction on collectively owned farms in the Besters district acquired through the post-Apartheid government's land redistribution programme. ${ }^{11}$ Land reform beneficiaries engage in commercial beef production, mostly from collectively owned cattle herds, but combined, in complex and variable ways, with multiple-function livestock herds owned by individual households. Customary norms and values inform social organisation, property holding and production, in a manner that is similar to, but also subtly different from, communal areas. The case illustrates the significance of the livestock and the ceremonial 'fund' for social reproduction, but their interactions with wage income and commodity production are key to complex and differentiated social dynamics. Tensions over the distribution and uses of cash income generated by collectively owned cattle herds in particular generate a local politics centred on the contradictions between accumulation and social reproduction.

The Besters Land Reform Project is located in the north-west of KwaZulu-Natal province, in an agro-ecological zone suited to cattle farming. From 2005, negotiations were initiated between commercial farm owners and labour tenants to resolve tenants' land claims. These led to the transfer of approximately 21 percent of privately owned farmland in the district to groups of labour tenant households and other farmworkers. A total of 178 households benefitted from transfers of land, cattle and agricultural implements, at a total cost of around R25 million. Thirteen communal property associations (CPAs) were established to take ownership of the farms, ranging from three to 28 member households per CPA, and managed on behalf of members by elected committees. By 2006, white landowners had been paid market prices for the land, and beneficiaries were beginning to sell weaned oxen in local auction sales and informal markets - a rare land reform 'success story'.12

Research on six of the 13 farms revealed that in 2010 beneficiary households owned a total of 1813 cattle, with a mean household herd size of 22 and a range of zero to 154 cattle. ${ }^{13}$ Four of the six CPAs owned cattle in their own right, and operated commercial beef production enterprises on some parts of the farm, while the other two CPAs had reallocated all of their cattle to member households. The total stock of CPA cattle in 2010 amounted to 529 head, with a mean herd size of 132, ranging between 15 and 278 head. Cattle production on these farms is organised at both household and CPA levels, with CPA herds sometimes kept in separate paddocks.

CPA beef herds often provide cross-subsidies, in kind, cash or breeding stock, to household herds.

\footnotetext{
11 This case is based on Hornby (2015).

${ }^{12}$ Initially the beneficiaries also engaged in maize and soya production, but cropping has declined both on these land reform farms and on commercial farms across the district more generally. Homesteads often include gardens for vegetable production, however.

${ }^{13}$ These household herd sizes are markedly higher than in most communal area contexts; e.g. in Msinga in 2014 the mean herd size for all households was 4.5 cattle (MRDP 2015).
} 
Farming is only one of a number of livelihood strategies that beneficiaries pursue. A survey in 2010 revealed fewer people secured incomes from farming ( 21 percent) than from employment (54 percent) and social grants (38 percent), and around five percent derived cash income from CPA dividends or employment. However, the distribution of income from these multiple sources was uneven. ${ }^{14}$ Of the 60 households earning an income from employment, the top quartile received 54 percent of the total income and the bottom quartile only 7.5 percent. The distribution of household farming was even more skewed, with the top quartile receiving 71 percent of total farming income, while the bottom quartile received just three percent.

Households in the wealthiest asset group, which own nearly double the number of assets owned by the population as a whole, also own more than half the total number of cattle, have a greater number of income sources, and are least likely to be headed by women. More than two-thirds (70 percent) of female-headed households are found in the two poorer asset quartiles. The unequal wealth structure thus reflects both livelihood diversification and differential capacities to engage in farm production, and is clearly highly gendered.

Accumulation through cattle production is occurring in some CPA households, but it is not the number of livelihoods as such that shapes accumulation, but rather how key variables interact with each other. These include the depth of income sources (in terms of both range and number); the impact of household shocks, particularly the death, retrenchment or long-term unemployment of a household head; cattle deaths, fertility problems and stock theft; the numbers of cattle originally acquired, particularly via inheritance; and whether or not CPA production supports household farming activities, and to what extent.

Sharp declines in some households' production result from high rates of herd off-take (through sales and the ceremonial use of cattle) exceeding rates of replacement in raising calves, purchases, bridewealth and other cattle transfers. However, where CPAs disburse surplus cattle (often young females, or heifers) to household members and subsidise household farming (through inputs and labour) to a significant degree, households are able to re-invest in cattle production and reverse the decline in herd sizes, or maintain their cattle herds at more or less constant numbers. Some households that have had no significant recent shocks to their livelihood portfolios, and have also received cattle and farm subsidies from the CPA, can expand their cattle herds and diversify their livelihood sources. Where households receive no cattle or subsidies from the CPA, the farmers most likely to expand cattle production are those with larger herds (accumulated prior to land reform in particular kinds of labour tenant arrangements) and thus able to appropriate a larger share of grazing land.

\footnotetext{
${ }^{14}$ On the basis of survey data, different 'asset groups' were created by organising households hierarchically into four quartiles based on the total number of assets (domestic, agricultural, communication and transport) owned, as a proxy for wealth status. Households accumulating wealth were distinguished from those whose wealth status remained stable, those diversifying their livelihood sources in order to maintain themselves, and those who were struggling to reproduce themselves. This analysis did not employ class categories, but demonstrated differences in livelihood trajectories explicable using a class-analytic approach (cf. Scoones et al. 2012; Dubb 2015).
} 
CPAs as separate farm enterprises struggle to balance three competing demands on their profits: (1) using income from cattle sales to meet their own operational requirements, particularly wages, nutritional supplements, veterinary inputs, breeding, maintaining infrastructure and purchase of farm implements (i.e. simple reproduction of the enterprise); (2) investing in expanding production, improving labour productivity, investing up or down the value chain, and attempts to secure niche markets (i.e. expanded reproduction of the enterprise); and (3) providing member households with benefits in the form of cash dividends, heifers, subsidised inputs to household farming or burial insurance (i.e. supporting social reproduction or household-based accumulation). Where CPA production supports household farm production in these ways, households often continue farming as part of a mixed livelihood strategy. Tensions between these competing pressures on CPA herds are at the centre of the many conflicts which have emerged on these farms.

When CPAs are unable to provide members with substantial and increasing benefits, members question how farms are managed, and suspicions that farm income is being appropriated by CPA leaders sometimes emerge. In some cases, these have led to all CPA cattle being reallocated to member households, disbanding the CPA beef enterprise. In these CPAs, poorer households tend to fall out of farm production, placing further pressure on their social reproduction. On farms where CPAs no longer engage in beef cattle production, class differentiation is clearly more pronounced than on those with profitable CPA cattle enterprises. In the latter, the gap between better off farmers and the farming poor is gradually becoming narrower. Accumulation thus articulates with social reproduction in a complex manner, depending on local institutional configurations.

The Besters case also demonstrates the importance of the 'ceremonial fund' in rural South Africa. Livestock play key roles in three types of ceremony at Besters - marriage, funerals and Christmas festivities. Marriage involves a number of transactions and inter-family engagements, the main ones being bridewealth, the transfer of gifts from a man's family to his future wife's family, and the transfer of gifts from the wife's family to her husband's family. In addition, aspects of European weddings have been incorporated into the final ceremony, which occurs over two days. The first day occurs at the bride's natal home and includes exchanges of rings and a religious sermon, and the second day at the groom's home, where dancing occurs along with invoking the lineage and its ancestors, to whom the new wife is introduced.

In the year 2010, approximately 2.7 percent of the total cattle owned by individual households on the six farms were used in ceremonial slaughter, by a third of all households. Of these households, 53 percent slaughtered one animal, 37 percent slaughtered two cattle and the remaining 10 percent slaughtered either three or four cattle. The total value of these slaughtered cattle was approximately R244,000, or between R4900 and R19,800 per household. Agreements to pay lobolo involved as few as six cattle to as many as 15 cattle. In addition, cattle sales are crucial for generating the cash to cover the costs of purchasing gifts and holding marital ceremonies. In one case, wedding costs 
amounted to around R82,00o, and required the sale of 13 lobolo cattle and five other cattle, and involved the slaughter of three cattle and four goats, in addition to cash derived from the wages of the bridegroom. Similarly, ceremonies relating to the dead are also extended affairs, in some cases involving the slaughter of four to five cattle and several goats.

Not all households on the Besters land reform farms own the four or five cattle, the herds of goats or the cash required to fund such lavish marriage or mourning feasts. This is reflected in a new idiom for burial ceremonies: a 'bus ceremony' is one where cattle are slaughtered, and is well attended by families and neighbours, and is distinguished from a 'taxi ceremony', where only a goat is slaughtered and far fewer people attend. Ceremonies involve the distribution of meat, food and drink, easing the pressure on the social reproduction of poor households to a degree, but also serve to bolster the social status and esteem of wealthier households and their ability to influence CPA decisions. Differential capacity to fund expenditure on ceremonies, a key aspect of social reproduction at Besters, thus both reflects and tends to further deepen social differentiation within land-holding groups.

The Besters case illustrates the complex and shifting relations between wage labour, agricultural commodity production, and state welfare grants in the social reproduction of households located in South Africa's rural areas. For some households on land reform farms, income sources are mutually supportive and enable increased levels of income and even accumulation, but for others, declining cattle herds both reflect and contribute to a diminished capacity to secure their reproduction. The profitability of CPA cattle enterprises and the distribution of surplus income are at the centre of a range of tensions and conflicts on land reform farms in Besters populated by both 'fragmented classes of labour' and aspiring rural accumulators.

\section{Social reproduction in rural South Africa: lessons from the case studies}

The cases described above illustrate key aspects of social reproduction in rural South Africa. Firstly, land and property rights are significant in a variety of ways, despite the relatively small contributions of agricultural production to the incomes of most households. Land is pivotal for the establishment of a homestead, the locus of daily and generational reproduction, which is why customary norms and practices offering guaranteed and free access to land to accepted community members remain important. This resonates with Ferguson's (2013) arguments that land anchors a range of 'distributive relations' that involve claims on a 'rightful share' of resources held by families and networks of kin, including cash from social grants.

Secondly, rural homes offer key advantages for South Africans belonging to 'fragmented classes of labour' (an appropriate characterisation for most members of rural households). The cost of living in communal areas and on land-reform farms is significantly lower than in urban contexts, partly because homes are cheaper to build and maintain, but also because infrastructure has been greatly improved by state investment, with 
services such as water, electricity, health and education offered at little or no cost. Care of children and the old at rural homes helps to anchor family structures and kinship networks, at a time when employment prospects are bleak and livelihood strategies are precarious.

Thirdly, communal areas and land-reform farms involve rights to landed resources, used for the production of supplementary food and livestock and gathering of wild resources for consumption and sale (Shackleton, Shackleton, and Cousins 2001). Production of dryland crops such as the staple, maize, continues to decline, unsurprisingly given the high levels of productivity and efficiency of large-scale commercial farmers, together with easy access to maize meal in retail outlets. In relation to irrigated crops and livestock, however, considerable amounts of cash income can be earned by a minority of better off households, often those with members in secure and well-paid employment. Agriculture thus also creates opportunities for accumulation, albeit limited.

Fourthly, given that access to productive land is mediated by either 'customary' norms and values (communal areas), or collective property institutions (land reform farms), incipient processes of accumulation generate tensions and conflicts over the prospects for unequal benefits from shared resources. On Besters land-reform farms, this has resulted in CPAs becoming the site of contestations over how cattle production should be organised. In the Msinga irrigation schemes, greatly expanded access by would-be accumulators to irrigated plots (e.g. through the informal rental market) would undoubtedly generate similar tensions if attempted, since it would constitute a threat to the key role of fresh produce income in social reproduction. The informal land market in irrigated plots allows for expanded access to a limited degree, given that it is 'socially embedded' (only partially commoditised); this constitutes a key constraint on accumulation.

Fifthly, customary institutions give rise to a ceremonial economy with two key features: (1) considerable amounts of cash (the so-called 'ceremonial fund') are spent in reproducing forms of 'the social' premised on the interdependence of individuals within families, kin networks and 'communities', and expressed in rituals surrounding marriage, death and celebrations. There is great variation in the degree to which households can afford to spend cash on such ceremonies, reflecting the social differentiation of social reproduction; and (2) livestock play key roles in ceremonies, which support a large and lucrative market in live animals for slaughter. Most livestock production takes place on communal grazing, a shared resource which benefits larger herd owners more than those with smaller herds or who own no animals at all.

Sixthly, social institutions such as marriage are in flux, and many women bear children outside of stable relationships. Many rural homesteads include adult females with children, leading to a range of conflicts and tension, and 'customary' relations and identities are being both affirmed and subverted in processes of land allocation to female-headed households. 'Custom' is increasingly a site of contestation between men and women, older and younger generations, and accumulators and 'classes of labour'. 
Seventhly, household strategies for securing social reproduction are deeply conditioned by the historical/structural impacts of capitalist development in South Africa, past and present, and shaped by processes of class differentiation both in society at large and locally. This means that social reproduction in rural South Africa is fraught with contradictions and tensions, and is thus a site of conflict as well as much social solidarity. A range of tensions, along axes of gender and generation, but also class, underpin localised forms of politics.

\section{Conclusion: social reproduction in rural areas elsewhere in the Global South}

Capitalist development in South Africa was shaped in fundamental ways by the specific manner in which class and race differences were combined in its early history. Twentythree years after the end of apartheid, the structural legacies of this history continue to present major challenges to efforts to reduce poverty and inequality. What makes South Africa a somewhat unique case in the Global South is the degree to which the land-based livelihoods of the rural population have been rendered marginal, with few compensating employment opportunities, as well as the extent of state transfers to the poor.

Nevertheless, we argue that key differences between South Africa and other countries with large populations of rural poor are likely to be of extent rather than of kind. The conditions under which rural populations across many parts of the world today have to seek their social reproduction are present in an exaggerated form in South Africa, but are not fundamentally different, in our view. ${ }^{15}$ Here we note some key similarities in relation to labour migration, social protection, the increasing marginalisation of small-scale farming, and the contradictory relationship between accumulation and social reproduction in rural economies.

The system of labour migration established to supply cheap labour to the South African mining industry in the early twentieth century was regional in scope, and many rural areas in neighbouring countries (e.g. Lesotho, Swaziland, Botswana) had the character of labour reserves. Labour migration remains a common feature of rural areas across Africa more widely, and it continues to be so today in many regions of the world. It is increasingly associated with the informalisation and casualisation of employment. Rural homes across the globe are bases for mobile or 'footloose' working populations engaged in 'fragmented' (diversified, but survivalist) livelihoods (Bernstein 2010; Li 2009).

While few countries in the Global South can afford to offer social protection on the scale of South Africa, many are experimenting with cash transfers, food aid, public works, and measures aimed at strengthening food security, such as input subsidies and construction of rural infrastructure (Devereux 2012; Li 2009). These form part of the conditions of social reproduction for increasing numbers of the rural poor. 
The marginalisation of small-scale agriculture is a core feature of many countries in the Global South, as is the paucity of formal employment and generalised rural poverty (Bryceson 2004). Despite widespread 'de-agrarianisation', however, access to land remains key for social reproduction. Social relations and identities in rural areas continue to be heavily influenced by cultural norms and values, whether framed in terms of custom or not.

A key issue that arises from the South African case is the relationship between social reproduction and capitalist accumulation. Marxism argues that this is inherently contradictory, although there have been times and places, perhaps exceptional in character, when growth and social provision have been complementary. In agrarian settings, the manner in which social reproduction occurs can facilitate accumulation, but in other cases acts as a key constraint on accumulation. More broadly, as in the debate on South Africa's accumulation path (Arrighi, Aschoff, and Scully 2010), the dynamics of social reproduction in rural settings may act as a powerful constraint on capitalist development more generally. Comparative analyses of countries with large rural populations, such as China, India, Brazil and South Africa, might yield insights on this issue.

We argue that the dynamics of social reproduction are a key aspect of contemporary capitalism deservedly receiving greater attention. In the rural areas of the Global South, these involve a great deal more than care work, domestic labour and struggles over social provision, important though these be. In particular, the social relations through which households, families and communities are constituted need to be taken into account, and land and its subtle and varied roles in social reproduction are critically important. Gender relations are of course central to social reproduction, as are other social differences that intersect with class, but their content as well as the culturally specific forms they take is highly variable.

Much of the material discussed in this contribution is well known; in many ways, we have simply re-framed data from existing literatures on South African poverty, social protection, rural livelihoods and land tenure in relation to wider unfolding theories of social reproduction. One advantage of a Marxist lens on these issues, however, is that it suggests that the spheres of production and reproduction should be analysed simultaneously, and in relation to each other. This 'totalising' or systemic view is a key strength of Marxist political economy. This is in contradistinction to the tendency in non-Marxist scholarship to simply assume that capitalism exists, and furthermore will always exist, which means that the effects of its contradictory relations can be studied and the policy (or political) implications explored, without critically investigating those relations themselves. In our view, social reproduction and its contradictions and contestations are key to struggles both within and against capitalism as such, and are as significant as the dynamics of production and capital accumulation. Marxist scholarship would do well to focus on them in more depth. 


\section{Acknowledgements}

Many thanks to Henry Bernstein for his helpful comments on an early draft of this piece, and to participants in a PLAAS Writing Workshop in 2017 who provided feedback on the basic arguments in the paper. Thanks also to the four anonymous reviewers whose remarks helped us to improve the paper.

\section{Disclosure statement}

No potential conflict of interest was reported by the authors.

\section{Funding}

The research on which this contribution is based was funded by the National Research Foundation of South Africa [Grant 71187]. 


\section{References}

Alexander, P., C. Ceruti, K. Motseke, M. Phadi, and K. Wale. 2013. Class in Soweto. Durban: University of KwaZulu-Natal Press.

Andersson, N., and S. Marks. 1988. "Apartheid and Health in the 1980s." Social Science \& Medicine 27 (7): 667-681.

Arrighi, G., N. Aschoff, and B. Scully. 2010. "Accumulation by Dispossession and Its Limits: The Southern Africa Paradigm Revisited." Studies in Comparative International Development 45 (4): 410-438.

Bakker, I., and R. Silvey. 2008. "Introduction: Social Reproduction and Global Transformations - from the Everyday to the Global." In Beyond States and Markets: The Challenges of Social Reproduction, edited by I. Bakker, and R. Silvey, 1-15. London/New York: Routledge.

Bernstein, H. 1986. "Capitalism and Petty Commodity Production." Social Analysis 20: 1128. Bernstein, H. 1996. "The Agrarian Question in South Africa: Extreme and Exceptional?” Journal of Peasant Studies 23 (2-3): 1-52.

Bernstein, H. 2006. "Is There an Agrarian Question in the 21st Century?" Canadian Journal of Development Studies 27: 449-460.

Bernstein, H. 2010. Class Dynamics of Agrarian Change. Halifax: Fernwood Press.

Bhattacharya, T. 2017. "How Not to Skip Class: Social Reproduction of Labor and the Global Working Class." In Social Reproduction Theory. Remapping Class, Recentering Oppression, edited by T. Battacharya, 55-72. London: Pluto Press.

Bhorat, H., M. Buthelezi, I. Chipkin, S. Duma, L. Mondi, C. Peters, M. Qobo, M. Swilling, and H. Friedenstein. 2017. Betrayal of the Promise. How South Africa is Being Stolen. Centre for Complex Systems in Transition (University of Stellenbosch), Public Affairs Institute (University of, Witwatersrand), Development Policy Research Institute, University of Cape Town), South African Research Chair in African Diplomacy and Foreign Policy (Johannesburg: University of Johannesburg).

Bhorat, H., A. Hirsch, R. Kanbur, and M. Ncube. 2014. "Economic Policy in South Africa Past, Present and Future." In The Oxford Companion to the Economics of South Africa, edited by H. Bhorat, A. Hirsch, R. Kanbur, and M. Ncube, 1-25. Oxford: Oxford University Press.

Bosiu, T., N. Nundu, A. Paelo, M. O. Thasago, and T. Vilikazi. 2017. "Growth and Strategies of Large and Leading Firms - Top 50 Firms on the Johannesburg Stock Exchange." Centre for Competition, Regulation and Economic Development. Working Paper 17/2017. Johannesburg, University of Johannesburg.

Bryceson, D. F. 2004. "Agrarian Vista or Vortex: African Livelihood Policies." Review of African Political Economy 31 (102): 617-629.

Burawoy, M. 1976. "The Functions and Reproduction of Migrant Labor: Comparative Material From Southern Africa and the United States." American Journal of Sociology 81 (5): 1050-1087.

Byres, T. J. 1996. Capitalism from Above and Capitalism from Below. An Essay in Comparative Political Economy. London: Macmillan.

Capps, G. 2016. "Tribal-Landed Property: The Value of the Chieftaincy in Contemporary Africa." Journal of Agrarian Change 16 (3): 452-477. 
Capps, G., and S. Mnwana. 2015. "Claims from Below: Platinum and the Politics of Land in the Bakgatla-ba-Kgafela Traditional Authority Area." Review of African Political Economy 42 (146): 606-624.

Chung, Y. B. 2017. "Engendering the New Enclosures: Development, Involuntary Resettlement and the Struggles for Social Reproduction in Coastal Tanzania." Development and Change 48 (1): 98- 120.

Claassens, A. 2015. "Law, Land and Custom, 1913-2014: What is at Stake Today?" In Land Divided, Land Restored. Land Reform in South Africa for the 21sr Century, edited by B. Cousins, and C. Walker, 68-84. Johannesburg: Jacana Media.

Cousins, B. 2011. Imithetho yomhlaba yaseMsinga: The Living Law of land in Msinga, KwaZulu-Natal. Research Report 43. Cape Town: Institute for Poverty, Land and Agrarian Studies, University of the Western Cape.

Cousins, B. 2013a. "Smallholder Irrigation Schemes, Agrarian Reform and 'Accumulation from Above and from Below' in South Africa." Journal of Agrarian Change 13 (1): $116-139$.

Cousins, B. 2013b. "Women's Land Rights and Social Change in Rural South Africa: The Case of Msinga, Kwazulu-Natal." In Marriage, Land and Custom, edited by A. Claassens, and D. Smythe, 73-99. Cape Town: UCT Press.

Devereux, S. 2012. "Social Protection for Enhanced Food Security in Sub-Saharan Africa." Working Paper WP 2012-010. Nairobi: United Nation Development Programme, Regional Bureau for Africa.

Dubb, A. 2015. "Dynamics of Decline in Small-Scale Sugarcane Production in South Africa: Evidence from Two 'Rural' Wards in the Umfolozi Region." Land Use Policy 48: 362376.

Ferguson, J. 2013. "How to Do Things with Land: A Distributive Perspective on Rural Livelihoods in Southern Africa." Journal of Agrarian Change 13 (1): 166-174.

Ferguson, J. 2015. Give a Man a Fish: Reflections on the New Politics of Distribution. Durham: Duke University Press.

Ferguson, S., G. LeBaron, A. Dimitrikaki, and S. Farris. 2016. "Special Issue on Social Reproduction. Introduction." Historical Materialism 24 (2): 25-37.

Fine, B., and Z. Rustomjee. 1996. The Political Economy of South Africa: From MineralsEnergy Complex to Industrialization. London: Zed Books.

Fine, B., and A. Saad-Filho. 2016. Marx's Capital. London: Pluto Press.

Fraser, N. 2016. "Contradictions of Capital and Care." New Left Review 100: 99-117. Gelb, S.1991. South Africa's Economic Crisis. Cape Town: David Philip.

Gibbon, P., and M. Neocosmos. 1985. "Some Problems in the Political Economy of "African Socialism'." In Contradictions of Accumulation in Africa. Studies in Economy and State, edited by H. Bernstein, and B. K. Campbell, 153-206. Beverly Hills: Sage.

Harriss-White, B. 2012. "Capitalism and the Common man: Peasants and Petty Production in Africa and South Asia." Agrarian South: Journal of Political Economy 1 (2): 109160.

Hart, G. 2002. Disabling Globalization: Places of Power in Post-Apartheid South Africa. Durban: University of KwaZulu-Natal Press. 
Hornby, D. 2015. "Cattle, Commercialisation and Land Reform: Dynamics of Social Reproduction and Accumulation in Besters, KwaZulu-Natal." PhD thesis, University of the Western Cape.

Hunter, M. 2007. "The Changing Political Economy of sex in South Africa: The Significance of Unemployment and Inequalities to the Scale of the AIDS Pandemic." Social Science \& Medicine 64 (3): 689-700.

Innes, D. 1984. Anglo: Anglo American and the Rise of Modern South Africa. Johannesburg: Ravan Press. Katz, C. 2001. "Vagabond Capitalism and the Necessity of Social Reproduction." Antipode 33 (4): 708-727.

Laslett, B., and J. Brenner. 1989. "Gender and Social Reproduction: Historical Perspectives." Annual Review of Sociology 15 (1): 381-404.

Legassick, M. 1980. "South Africa: Forced Labour, Industrialisation and Racial Differentiation." In The Political Economy of Africa, edited by R. Harris, 229-270. New York: John Wiley.

Lerche, J. 2011. "Agrarian Crisis and Agrarian Questions in India." Journal of Agrarian Change 11 (1): 104-118.

Lerche, J. 2013. "The Agrarian Question in Neoliberal India: Agrarian Transition Bypassed?" Journal of Agrarian Change 13 (3): 382-404.

Li, T. M. 2009. "To Make Live or Let Die? Rural Dispossession and the Protection of Surplus Populations." Antipode 41 (s1): 66-93.

Marx, K. 1976. Capital, Volume 1. Harmondsworth: Penguin.

Mdukatshani Rural Development Programme. 2015. Msinga Goat Agribusiness Project. Presentation to Treasury. Msinga: Mdukatshani Rural Development Programme.

Meillassoux, C. 1972. "From Reproduction to Production: A Marxist Approach to Economic Anthropology." Economy and Society 1 (1): 93-105.

Mezzadri, A. 2016. "Class, Gender and the Sweatshop: On the Nexus between Labour Commodification and Exploitation." Third World Quarterly 37 (10): 1877-1900.

Mezzadri, A., and R. Srivastara. 2015. Labour Regimes in the Indian Garment Sector: Capital-Labour Relations, Social Reproduction and Labour Standards in the National Capital Region. Report of the ESRC-DFID Research Project, 'Labour Standards and the Working Poor in India and China'. London: Centre for Development Policy and Research, School of Oriental and African Studies.

Naidu, S. C., and L. Ossome. 2016. "Social Reproduction and the Agrarian Question of Women's Labour in India." Agrarian South: Journal of Political Economy 5 (1): 5076.

Neves, D., and A. Toit. 2013. "Rural Livelihoods in South Africa: Complexity, Vulnerability and Differentiation." Journal of Agrarian Change 13 (1): 93-115.

O'Laughlin, B. 1996. "Through a Divided Glass: Dualism, Class and the Agrarian Question in Mozambique." Journal of Peasant Studies 23 (4): 1-39.

O'Laughlin, B. 2013. "Land, Labour and the Production of Affliction in Rural Southern Africa." Journal of Agrarian Change 13 (1): 175-196.

O'Laughlin, B. 2017. "Consuming Bodies: Health and Work in the Cane Fields of Xinavane, Mozambique." Journal of Southern African Studies 43 (3): 625-641. 
Picchio, A. 1992. Social Reproduction: The Political Economy of the Labour Market. Cambridge: Cambridge University Press.

Platzky, L., and C. Walker. 1985. The Surplus People. Forced Removals in South Africa. Cape Town: David Philip.

Posel, D., and S. Rudwick. 2013. "Changing Patterns of Marriage and Cohabitation in South Africa." Acta Juridica 2013 (1): 169-180.

Razavi, S. 2009. "Engendering the Political Economy of Agrarian Change." Journal of Peasant Studies 36(1): 197-226.

Sayer, A. 2010. Method in Social Science. revised 2nd ed. London: Routledge.

Scoones, I., N. Marongwe, B. Mavedzenge, F. Murimbarimba, J. Mahenehene, and C. Sukume. 2012. "Livelihoods after Land Reform in Zimbabwe: Understanding Processes of Rural Differentiation." Journal of Agrarian Change 12 (4): 503-527.

Seekings, J., and N. Nattrass. 2015. Policy, Politics and Poverty in South Africa. New York: Macmillan Palgrave.

Shackleton, C. M., S. E. Shackleton, and B. Cousins. 2001. "The Role of Land-Based Strategies in Rural Livelihoods: The Contribution of Arable Production, Animal Husbandry and Natural Resource Harvesting in Communal Areas in South Africa.” Development Southern Africa 18(5):581-604.

Southall, R. 2016. The New Black Middle Class in South Africa. Johannesburg: Jacana Media.

Statistics SA. 2016. Mid-Year Population Estimates, 2016. Statistical Release PO302. Pretoria: Statistics South Africa.

Statistics SA. 2017a. Quarterly Labour Force Survey, Second Quarter 2017. Statistical Release PO211. Pretoria: Statistics South Africa.

Statistics SA. 2017b. General Household Survey, 2016. Statistical Release PO318. Pretoria: Statistics South Africa.

Stevano, S. 2017. "The Limits to Instrumentalism: Informal Work and Cycles of Gendered Food Insecurity in Mozambique." Journal of Development Studies. doi:10.1080/00220388.2017.1408793. Vogel, L. 1983. Marxism and the Oppression of Women: Toward a Unitary Theory. New Brunswick: Rutgers University Press.

Wolf, E. 1966. Peasants. Englewood Cliffs, NJ: Prentice-Hall.

Wolpe, H. 1972. "Capitalism and Cheap Labour Power: From Segregation to Apartheid." Economy and Society 1 (4): 425-456.

Zizzamia, R., Schotte, S., Leibbrandt, M., \& Ranchhod, V. 2016. "Vulnerability and the Middle Class in South Africa." SALDRU Working Paper 188. Cape Town: Southern African Labour and Development Research Unit, University of Cape Town.

Ben Cousins holds a DST/NRF Research Chair in Poverty, Land and Agrarian Studies at the University of the Western Cape, and undertakes research on agrarian change, land reform, property rights and smallholder agriculture in Southern Africa.Email: bcousins@plaas.org.za

Alex Dubb is a PhD student at the Institute for Poverty, Land and Agrarian Studies (PLAAS) at the University of the Western Cape, focusing on the grain-livestock complex in South Africa. He has published extensively on the sugar industry in Southern Africa. Email: alexander.dubb@gmail.com 
Donna Hornby is a post-doctoral student at the Institute for Poverty, Land and Agrarian Studies (PLAAS) at the University of the Western Cape. She undertakes research on farm dwellers and former labour tenants in KwaZulu-Natal and works closely with civil society organisations in the land sector. Email: donnahornby@gmail.com

Farai Mtero is a senior researcher at the Institute for Poverty, Land and Agrarian Studies (PLAAS) at the University of the Western Cape. He is currently leading a research project on land redistribution in South Africa.Email: mtero2001@yahoo.com 